\title{
Levels of metabolizable energy and digestible lysine for broiler chicks 1-10 days of age
}

\section{Níveis de energia metabolizável e lisina digestível para pintos de corte de 1 a 10 dias de idade}

\author{
Ricardo Vianna Nunes ${ }^{1 *}$; Thaís Lorana Savoldi²; Cláudio Yuji Tsutsumi³; \\ Cleison de Souza ${ }^{4}$; Jomara Broch ${ }^{4}$; Sharon Karla Lüders Meza ${ }^{5}$; Liliane Borsatti ${ }^{6}$; \\ José Luiz Schneiders 5
}

\begin{abstract}
This study evaluated the effect of different levels of metabolizable energy (ME) and digestible lysine (DL) on the rate of protein deposition, rate deposition body fat and intestinal morphology of broiler chicks 1 to 10 days of age. The study design consisted of 1,152 broilers, weighing $52 \pm 5 \mathrm{~g}$, distributed in a completely randomized, $4 \times 4$ factorial design, consisting of four levels of ME $(2700 ; 2825 ; 2950$ and $3075 \mathrm{kcal} / \mathrm{kg}$ ) and four levels of DL $(1,080 ; 1,187 ; 1,295$ and 1,403\%), with 16 treatments and three replicates, with 24 poultry in each experimental unit. The protein deposition rate (PDR) and fat deposition rate $(F D R)$ were not affected $(\mathrm{P}>0.05)$ by the ME, however, PDR was influenced linearly $(\mathrm{P}<0.05)$ by increasing lysine. There was an interaction $(\mathrm{P}<0.05)$ between the levels of $\mathrm{ME}$ and $\mathrm{DL}$, whose increase resulted in a higher villus height of the duodenum, jejunum and a greater relation villus: crypt ratio of the ileum. Therefore, levels of DL and ME had positive effects on the intestinal development of broiler chicks in the pre-starter phase.
\end{abstract}

Key words: Amino acid. Poultry farming. Energy density. Morphology.

\section{Resumo}

O experimento foi realizado com o objetivo de avaliar o efeito dos níveis de energia metabolizável (EM) e de lisina digestível (LD), sobre a taxa de deposição de proteína, taxa de deposição gordura corporal e morfometria intestinal de pintos de corte de 1 a 10 dias de idade. Foram utilizados 1.152 pintos de corte, com peso médio de $52 \pm 5 \mathrm{~g}$, distribuídos em delineamento inteiramente casualizado, em esquema fatorial 4x4, constituídos quatro níveis de $\mathrm{EM}\left(2700 ; 2825 ; 2950\right.$; e $\left.3075 \mathrm{kcal}^{\mathrm{kg}} \mathrm{kg}^{-1}\right)$ e quatro níveis de $\operatorname{LD}(1,080 ; 1,187 ; 1,295$ e 1,403\%), com 16 tratamentos, três repetições e com 24 aves ME cada unidade experimental. A taxa de deposição de proteína (TDP) e de gordura (PDR) não foi influenciada $(\mathrm{P}>0,05)$ pelos níveis de $\mathrm{EM}$, no entanto, a PDR foi influenciada de forma linear $(\mathrm{P}<0,05)$ pelos níveis crescentes de lisina. Houve interação $(\mathrm{P}<0,05)$ entre os níveis de EM e DL, cujo aumento nesses níveis

\footnotetext{
${ }^{1}$ Prof. Dr., Programa de Pós-Graduação em Zootecnia, Universidade Estadual do Oeste do Paraná, UNIOESTE, Marechal Cândido Rondon, PR, Brasil. E-mail: nunesrv@hotmail.com

${ }^{2}$ Prof ${ }^{a}$, Curso de Medicina Veterinária, M.e em Zootecnia, Universidade Estadual de Maringá, UEM, Umuarama, PR, Brasil. Email: thaislorana@hotmail.com

${ }^{3}$ Prof. Dr., Curso de Agronomia, UNIOESTE, Marechal Cândido Rondon, PR, Brasil. E-mail: cytsutsu@uol.com

${ }^{4}$ Discentes do Curso de Doutorado do Programa de Pós-Graduação em Zootecnia, UNIOESTE, Marechal Cândido Rondon, PR, Brasil.E-mail: cleisondsz@hotmail.com; brochjomara@yahoo.com.br

5 Mestres em Zootecnia, Umuarama, PR, Brasil. E-mail: shakavet@hotmail.com; ze.luiz@zootecnista.com.br

${ }^{6} \mathrm{Dr}^{\mathrm{a}}$ em Zootecnia, Porto Alegre, RS, Brasil. E-mail: liliane_borsatti@yahoo.com.br

* Author for correspondence
} 
proporcionaram maior altura das vilosidades do duodeno, jejuno e na relação vilo:cripta do íleo. Os níveis de lisina digestível e energia metabolizável apresentam efeito positivo sobre o desenvolvimento intestinal dos pintos de corte na fase pré-inicial.

Palavras-chave: Aminoácido. Avicultura. Densidade energética. Morfometria.

\section{Introduction}

Advances in genetics research have enabled an improvement in feed conversion rates and carcass yield of broilers, which are determining factors from a nutritional point of view, considering that the phenotypic expression of genetic potential is influenced by the environment and nutrition. Thus, knowledge of the nutritional requirements for growth and development is important to obtain the maximum performance from the poultry.

Newly hatched poultry in the pre-initial phase undergo changes in their nutrition, as their nutritional requirements were previously obtained from the yolk sac, which is rich in proteins and lipids. Once hatched, they obtain their nutrition from supplied feed based on protein and complex carbohydrates (SAKOMURA et al., 2004).

According to Gonzales and Sartori (2002), the growth of muscle tissue is closely related to nutritional factors including the level of dietary amino acids, energy, vitamins and minerals, since the excess or deficiency of these nutrients can influence protein synthesis or degradation.

The correct ratio of amino acids that comprises the starter diets is currently formulated based on the ideal protein concept, which is to provide the proper amount of essential amino acids, without deficiency or excess. The amino acid lysine is used as a reference in the early stages, and is preferably intended for muscle deposition although some body parts respond better to increases in amino acid intake. High performance broilers require greater concentrations of lysine in the diet due to higher daily protein synthesis (TAKEARA et al., 2010).
Metabolizable energy (ME) is the term used to express the energy available and is commonly used in calculations of the nutritional value of poultry feed (NUNES et al., 2008). This is considered a strategic nutritional factor in production systems that use fed ad libitum, because food consumption is mainly regulated by the caloric density of rations, which may have implications on the productive and economic efficiency of poultry activity. The requirements for crude protein, amino acids and other nutrients are usually expressed in terms of levels of ME of feed (SILVA et al., 2003).

This study was conducted in order to establish the best level of ME and digestible lysine (DL) for broiler chickens in the pre-initial phase of 1 to 10 $\mathrm{d}$ of age, for the rate of fat deposition, rate of body protein deposition and morphometric features of the small intestine.

\section{Materials and Methods}

The experiment was conducted at the Experimental Station of poultry farming at Universidade Estadual do Oeste do ParanáUNIOESTE, and was approved by the ethics committee and the institution's biosafety protocol, Protocol 04511. The poultry were housed in boxes (experimental unit - UE), which had a tubular feeder, nipple-type water dispenser, hood heating (250 watt infrared lamps) and concrete floor, which was lined with pine shavings.

One thousand one hundred and fifty-two male broiler chicks, one day old, from the commercial line Cobb 500 and with an average weight of $52 \pm$ $5 \mathrm{~g}$ were used. The treatments were distributed in a completely randomized design in a $4 \times 4$ factorial 
design, consisting of four levels of Metabolizable energy (ME) (2700; 2825; 2950 and $3075 \mathrm{kcal} / \mathrm{kg})$ and four levels of digestible lysine (DL) $(1,080$; 1,$187 ; 1,295$ and $1,403 \%$ ) totaling 16 treatments with three repetitions of 24 poultry each. After the distribution of poultry, an additional group of five broilers were fasted for six hours and then killed by cervical dislocation and frozen at $-200{ }^{\circ} \mathrm{C}$ for later processing.

The experimental diets were formulated based on corn and soybean meal (Table 1), according to the composition of the food and nutritional requirements proposed by Rostagno et al. (2011), maintaining the relation ideal protein for methionine + cysteine $(71 \%)$, tryptophan (16\%), threonine $(65 \%)$, arginine $(105 \%)$, isoleucine $(65 \%)$ and valine $(75 \%)$.

At 10 days old, two animals per EU, with a range of $\pm 10 \%$ by weight processing, were fasted for six hours and weighed and killed by cervical dislocation for evaluation of body composition.

Carcasses of the additional group and the poultry slaughtered at 10 days were individually crushed and homogenized, and a sample of each bird was sent to an animal nutrition laboratory for predrying in a forced air oven at $550{ }^{\circ} \mathrm{C}$ for 72 hours, with subsequent pre-degreasing. The degreased carcasses were again crushed, and then submitted for analysis of dry matter, ether extract and crude protein, according to the methodology described by Silva and Queiroz (2004).

For determination of protein deposition rates (PDR) and fat deposition rates (FDR) in the carcass (g/day) the methodology adapted by Fraga et al. (2008) was used. A PDR was measured by comparing the chicks slaughtered at the end of the trial period with the additional group of five chicks slaughtered in the housing.
On the tenth day, two more poultry with the UE average weight $( \pm 10 \%)$ were slaughtered for the histomorphometric evaluation of the small intestine. The segments of the small intestine (duodenum, jejunum and ileum) were opened on the mesenteric border, and fragments of approximately $2.0 \mathrm{~cm}$ in length were carefully collected, washed in distilled water, extended the tunica serosa and fixed in buffered $10 \%$ formalin solution for 24 hours. After this period, they were subjected to several washes with $70 \%$ ethanol and kept in this solution to make the slides.

Subsequently, the samples were dehydrated in increasing alcohol solutions, cleared in xylene, embedded in paraffin wax and cut with a rotary microtome to $7 \mu \mathrm{m}$. Three blades were prepared per animal and each blade inserted semiserial four cuts. The sections were stained with hematoxylin-eosin.

The morphometric analysis of histologic sections was performed in the Motic Advanced 2.0 image analyzer, Animal Reproduction Sector CAU-MEU. Straight lengths were selected and measured in accordance with the adopted unit $(\mu \mathrm{m})$, 30 villi and 30 crypts and oriented. The villus height measurements were taken from the upper base of the crypt to the apex of the villus, and crypts were measured between the lower base of the villi to the upper base of the crypt.

Statistical analyses were performed with assistance of the Statistical Analysis System version 9 (SAS, 2002). Statistical analysis of the parameters was performed by PROC GLM $(\mathrm{P} \leq 0.05)$. The parameters in which significant differences were found $(\mathrm{P} \leq 0.05)$ were estimated by polynomial regression using the PROC REG. For interactions of ME x DL, significant $(\mathrm{P} \leq 0.05)$ response surface regressions were estimated using the PROC RSREG procedure as adjustment data. 


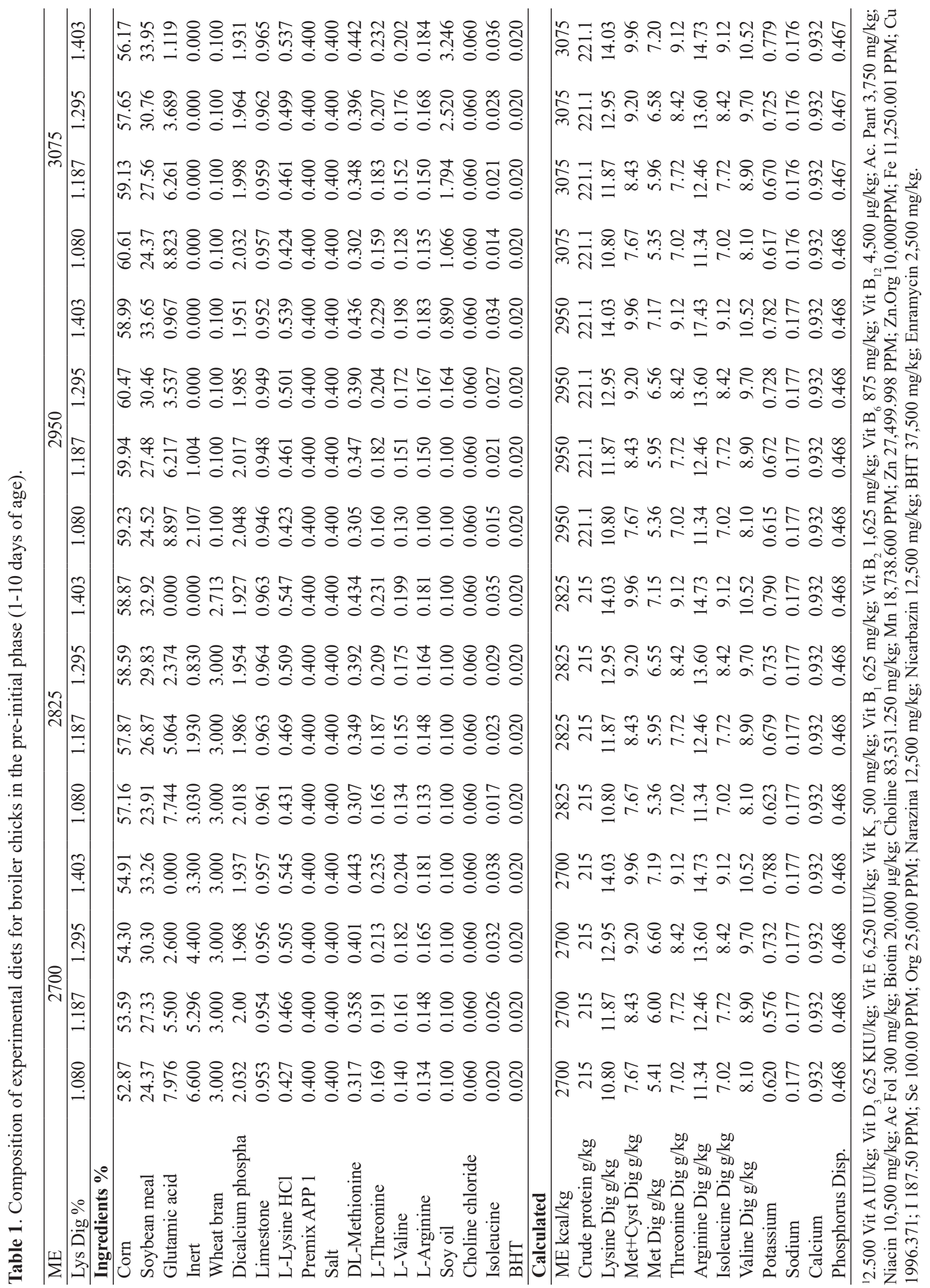




\section{Results and Discussion}

There was no interaction $(\mathrm{P}>0.05)$ between the levels of metabolizable energy (ME) and digestible lysine (DL) on the protein deposition rates (PDR) and fat deposition rates (FDR) in the carcasses of broiler chicks the pre-starter period (Table 2).

Table 2. Protein deposition rate and fat deposition rate in 10-day-old broilers.

\begin{tabular}{lccc}
\hline & & $\begin{array}{c}\text { PDR } \\
(\mathrm{g} / \text { day })\end{array}$ & $\begin{array}{c}\text { FDR } \\
\text { (g/day })\end{array}$ \\
\hline ME & & & \\
& 2700 & 3.114 & 1.891 \\
& 2825 & 2.93 & 1.721 \\
& 2950 & 3.09 & 2.014 \\
& 3075 & 3.076 & 2.051 \\
\hline Regression & & ns & ns \\
\hline LYS & $1.080 \%$ & 3.199 & 1.73 \\
& $1.187 \%$ & 2.985 & 1.818 \\
& $1.295 \%$ & 3.051 & 2.039 \\
& $1.403 \%$ & 2.993 & 2.114 \\
\hline Regression & & ns & L* \\
\hline CV(\%) & & 24.08 & 26.69 \\
Average & & 3.057 & 1.946 \\
\hline \multicolumn{2}{l}{} \\
\hline
\end{tabular}

$\mathrm{CV}=$ coefficient of variation, $\mathrm{ns}=$ not significant; $\mathrm{L} *=$ linear effect at 0.05 probability.

The levels of ME and DL did not influence $(\mathrm{P}>0.05)$ the PDR. These results were different from those found by Leandro et al. (2003), who evaluated different nutritional plans (energy and protein) and observed a linear increase in the PDR. The increase in protein deposition was related to the gradual improvement in the energy / protein ratio of feed, where the lowest levels were insufficient to ensure proper deposition rate.

DL levels had a linear influence $(\mathrm{P}<0.05)$ on FDR $\left(\mathrm{FDR}=0.33945+1.27416^{*} \mathrm{LYS} ; \mathrm{R}^{2}=\right.$ $0.94)$, but no differences were observed $(\mathrm{P}>0.05)$ in the levels of ME. These data differ from those found by Cella et al. (2009), who did not find a significant effect of different levels of DL in broiler chicks ranging from 1 to 21 days of age. However, Toledo et al. (2007) also did not find a significant effect of different levels of DL in the diet on the PDR and FDR of broiler chicks in the pre-initial phase.

In a study conducted by Nunes et al. (2015), the authors observed that the PDR and FDR were influenced by an increase in the levels of $\mathrm{ME}$ and DL in the feed, with the increase of ME being the main factor responsible for increasing the FDR. According to Silva et al. (2001), the accumulation of fat in the carcass is the result of energy intake beyond the needs for maintenance and muscle growth of poultry, as well as the increase of the ME: crude protein ratio. 
According to Vasconcellos et al. (2012), by reducing the concentration of protein and / or dietary amino acids, there is an increase in carcass fat content; therefore, it was understood that diets with high levels of protein and amino acids provide a lower body fat ratio, although the same was not observed in this experiment.
Different levels of ME and DL interacted to affect the duodenum villus height $(\mathrm{P}<0.05$; Table 3 ), with the best results obtained with reduced levels of ME and increased levels of DL (DVH $=-8315.6429+4.4169 * \mathrm{ME}+4678.6016 * \mathrm{LYS}-$ $0.0003 * \mathrm{ME}^{2}-2.2669 * \mathrm{ME}^{*} \mathrm{LYS}+864.125 * \mathrm{LYS}^{2}$; $\mathrm{R}^{2}=0.30$ ) (Figure 1).

Table 3. Means of intestinal morphometry of broiler chickens from 1 to 10 days of age treated with different levels of metabolizable energy and digestible lysine.

\begin{tabular}{|c|c|c|c|c|c|c|c|c|c|}
\hline & \multicolumn{3}{|c|}{ Duodenum } & \multicolumn{3}{|c|}{ Jejunum } & \multicolumn{3}{|c|}{ Ileum } \\
\hline & $\begin{array}{l}\text { Villus } \\
(\mu \mathrm{m})\end{array}$ & $\begin{array}{l}\text { Crypt } \\
(\mu \mathrm{m})\end{array}$ & $\begin{array}{l}\text { Villus } \\
\text { :Crypt }\end{array}$ & $\begin{array}{c}\text { Villus } \\
(\mu \mathrm{m})\end{array}$ & $\begin{array}{l}\text { Crypt } \\
(\mu \mathrm{m})\end{array}$ & $\begin{array}{l}\text { Villus:crypt } \\
(\mu \mathrm{m})\end{array}$ & $\begin{array}{l}\text { Villus } \\
(\mu \mathrm{m})\end{array}$ & $\begin{array}{l}\text { Crypt } \\
(\mu \mathrm{m})\end{array}$ & $\begin{array}{l}\text { Villus } \\
\text { crypt }\end{array}$ \\
\hline \multicolumn{10}{|l|}{$\mathrm{ME}$} \\
\hline 2700 & 1188.06 & 223.30 & 5.35 & 754.56 & 199.14 & 3.83 & 596.84 & 170.35 & 3.60 \\
\hline 2825 & 1203.90 & 261.78 & 4.66 & 769.64 & 205.58 & 3.79 & 623.31 & 196.39 & 3.19 \\
\hline 2950 & 1204.83 & 247.42 & 4.97 & 794.71 & 214.08 & 3.75 & 631.87 & 197.15 & 3.22 \\
\hline 3075 & 1203.74 & 223.16 & 5.40 & 850.28 & 231.42 & 3.71 & 677.60 & 201.71 & 3.37 \\
\hline Regression ME & ns & ns & ns & ns & ns & ns & $\mathrm{L}^{*}$ & $\mathrm{Q}^{*}$ & ns \\
\hline \multicolumn{10}{|l|}{ Lysina } \\
\hline 1.08 & 1162.06 & 230.29 & 5.10 & 718.82 & 210.29 & 3.47 & 588.09 & 185.11 & 3.21 \\
\hline 1.187 & 1184.49 & 232.85 & 5.10 & 753.74 & 212.36 & 3.60 & 607.80 & 187.36 & 3.30 \\
\hline 1.295 & 1195.67 & 238.62 & 5.18 & 794.80 & 213.36 & 3.75 & 652.68 & 194.15 & 3.42 \\
\hline 1.403 & 1258.32 & 253.89 & 5.01 & 901.83 & 214.21 & 4.25 & 681.05 & 198.97 & 3.46 \\
\hline Regression DL & ns & ns & ns & ns & ns & $\mathrm{L}^{* *}$ & $\mathrm{~L}^{* *}$ & ns & ns \\
\hline ME x DL & $\mathrm{RS}$ & RS & $\mathrm{RS}$ & $\mathrm{RS}$ & RS & ns & ns & ns & ns \\
\hline $\mathrm{CV}$ & 6.02 & 10.13 & 9.90 & 6.69 & 11.54 & 12.04 & 10.48 & 12.48 & 3.34 \\
\hline Average & 1200.13 & 238.91 & 5.09 & 792.29 & 212.55 & 3.76 & 191.39 & 191.39 & 14.45 \\
\hline \multicolumn{10}{|c|}{ Polynomial regression equations } \\
\hline \multicolumn{10}{|c|}{$\begin{array}{c}\mathrm{HIV}=52.946+0.2007 * \mathrm{ME} ; \mathrm{R}^{2}=0.89 \\
\mathrm{DIC}=-2886.3+2.0606 * \mathrm{ME}-0.0003 * \mathrm{ME}^{2} ; \mathrm{R}^{2}=0.93 \\
\mathrm{RVCJ}=0.90467+2.3069 * \mathrm{LYS} ; \mathrm{R}^{2}=0.88 \\
\mathrm{DVH}=259.18453+300.68148 * \mathrm{LYS} ; \mathrm{R}^{2}=0.98\end{array}$} \\
\hline
\end{tabular}

Response surface equations

$\mathrm{DVH}=-8315.6429+4.4169 * \mathrm{ME}+4678.6016 * \mathrm{LYS}-0.0003 * \mathrm{ME}^{2}-2.2669 * \mathrm{ME} * \mathrm{LYS}+864.125 * \mathrm{LYS}^{2} ; \mathrm{R}^{2}=0.30$

$\mathrm{DCD}=-8422.5127+6.0187 *$ ME-63.3877*LYS-0.001*ME2 $-0.1882 *$ ME*LYS $+273.0148 * \mathrm{LYS}^{2} ; \mathrm{R}^{2}=0.31$

$\mathrm{RVCD}=5.6713-0.4519 * \mathrm{ME}+1171.798 * \mathrm{LYS}+0.0002 * \mathrm{ME} 2-0.3789 * \mathrm{ME} * \mathrm{LYS}-26.5946 * \mathrm{LYS}^{2} ; \mathrm{R}^{2}=0.23$

$\mathrm{VHJ}=263.0311-0.9277 * \mathrm{ME}+2673.6663 * \mathrm{LYS}+0.0006 * \mathrm{ME2}-2.0659 * \mathrm{ME} * \mathrm{LYS}+1546.4099 * \mathrm{LYS}^{2} ; \mathrm{R}^{2}=0.71$

$\mathrm{CDJ}=5.6713-0.4519 * \mathrm{ME}+1171.798 * \mathrm{LYS}+0.0002 * \mathrm{ME}^{2}-0.3789 * \mathrm{ME} * \mathrm{LYS}-26.5946 * \mathrm{LYS}^{2} ; \mathrm{R}^{2}=0.23$

$\mathrm{CV}=$ coefficient of variation; $\mathrm{RS}=$ response surface; $\mathrm{L}=$ linear effect; $\mathrm{Q}=$ quadratic effect; $\mathrm{s}$ * and ** = not significant, meaningful $\mathrm{P}<0.01$ and $\mathrm{P}<0.05$, respectively; HIV = height of ileal villus; $\mathrm{DIC}=$ depth of ileal crypt; $\mathrm{RVCJ}=$ villus: crypt of jejunum; $\mathrm{DVH}=$ villus height of duodenum; DCD = depth of duodenal crypt; RVCD = villus: crypt of duodenum; VHJ= height of jejunum villus; $\mathrm{CDJ}=$ depth of jejunum crypt. 
Similarly, an interaction was observed $(\mathrm{P}<0.05)$ between the levels of $\mathrm{ME}$ and $\mathrm{DL}$ regarding the jejunum villus height $(\mathrm{VHJ}=263.0311$ $0.9277 * \mathrm{ME}+2673.6663 * \mathrm{LYS}+0.0006 * \mathrm{ME}^{2}-$ $\left.2.0659 * \mathrm{ME} * \mathrm{LYS}+1546.4099 * \mathrm{LYS}^{2} ; \mathrm{R}^{2}=0.71\right)$, with an increase in the size of villi observed with a reduction in the level of DL and an increased level of ME (Figure 2). The same behavior was observed for the ileal villus height $(\mathrm{P}<0.05)$.

Figure 1. Duodenal villus height depending on the levels of metabolizable energy and digestible lysine.

$\mathrm{DVH}=-8315.6429+4.4169 * \mathrm{ME}+4678.6016 * \mathrm{LYS}-0.0003 *$

$\mathrm{ME}^{2}-2.2669 * \mathrm{ME} * \mathrm{LYS}+864.125 * \mathrm{LYS}^{2},\left(\mathrm{R}^{2}=0.30\right)$

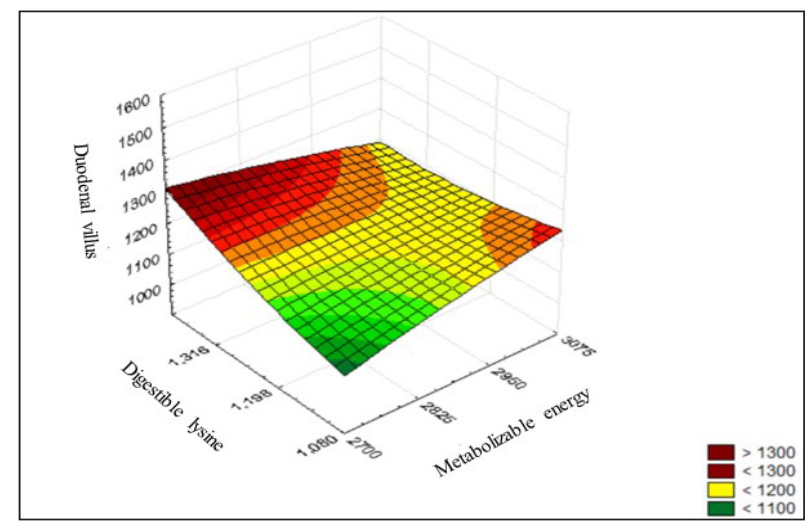

Figure 2. Villus height of the jejunum based on the levels of metabolizable energy and digestible lysine.

$\mathrm{VHJ}=263.0311-0.9277 * \mathrm{ME}+2673.6663 * \mathrm{LYS}+0.0006 *$ $\mathrm{ME}^{2}-2.0659 * \mathrm{ME} * \mathrm{LYS}+1546.4099 * \mathrm{LYS}^{2},\left(\mathrm{R}^{2}=0.71\right)$

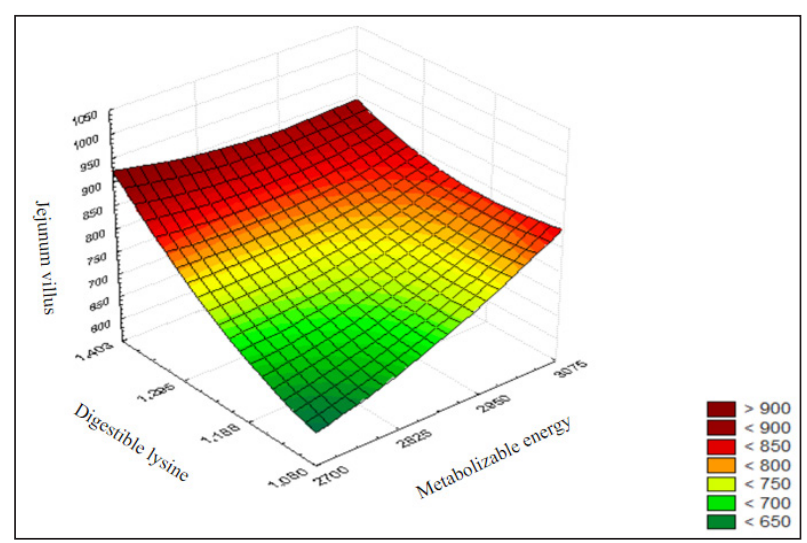

In the duodenum, an interaction was observed $(\mathrm{P}<0.05)$ between the levels of ME and DL regarding crypt depth $(\mathrm{DCD}=-8,422.5127+6.0187 * \mathrm{ME}-$ 63.3877*LYS - $0.001 * \mathrm{ME}^{2}-0.1882 * \mathrm{ME}^{*} \mathrm{LYS}+$ 273.0148*LYS $\left.{ }^{2} ; \mathrm{R}^{2}=0.31\right)($ Figure 3 ).

Figure 3. Duodenal crypt depth in terms of levels of metabolizable energy and digestible lysine.

$\mathrm{DCD}=-8422.5127+6.0187 *$ ME-63.3877*LYS-0.001* ME $^{2}-0.1882 *$ ME*LYS $+273.0148 * \mathrm{LYS}^{2},\left(\mathrm{R}^{2}=0.31\right)$

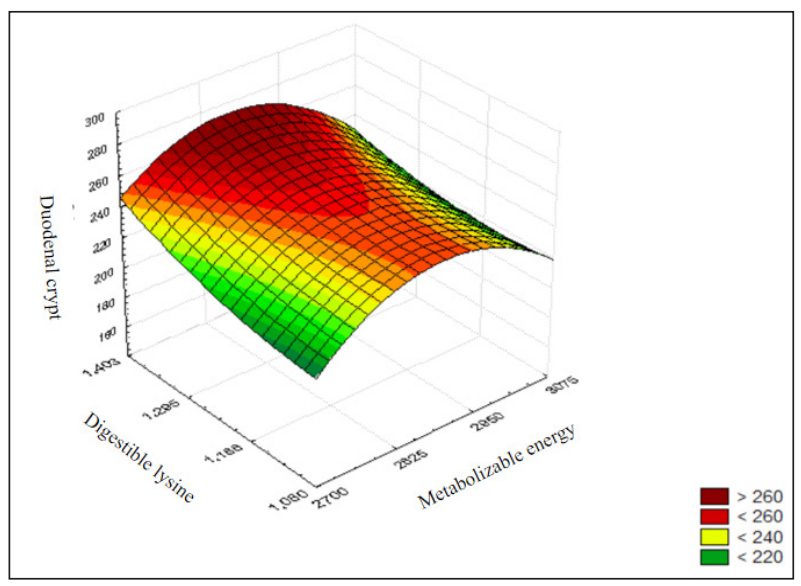

The jejunum crypt depth also showed an interaction $(\mathrm{P}<0.05)$ according to the levels of ME and DL $(\mathrm{CDJ}=5.6713-0.4519 * \mathrm{ME}+1171.798 * \mathrm{LYS}$ $+0.0002 * \mathrm{ME}^{2}-0.3789 * \mathrm{ME} * \mathrm{LYS}-26.5946 * \mathrm{LYS}^{2}$; $\mathrm{R}^{2}=0.23$ ), where the depths were observed with an increase in ME and a reduction in DL (Figure 4).

Figure 4. Crypt depth of the jejunum as a function of the levels of metabolizable energy and digestible lysine.

$\mathrm{CDJ}=5.6713-0.4519 * \mathrm{ME}+1171.798 * \mathrm{LYS}+0.0002 *$ $\mathrm{ME}^{2}-0.3789 *$ ME*LYS-26.5946*LYS $2,\left(\mathrm{R}^{2}=0.23\right)$

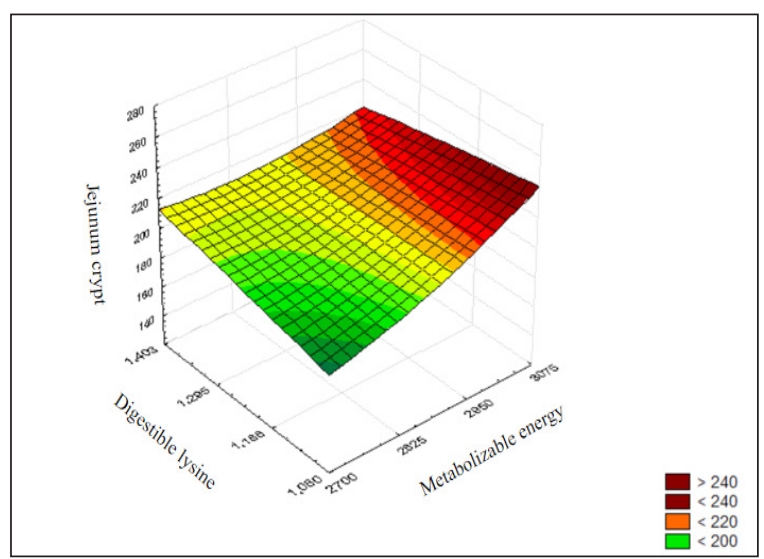


Regarding the duodenal villus height to crypt depth ratio, an interaction $(\mathrm{P}<0.05)$ was obtained between the levels of ME and DL (RVDC $=5.6713$ - $0.4519 * \mathrm{ME}+1171.798 * \mathrm{LYS}+0.0002 * \mathrm{ME}^{2}$ $-0.3789 *$ ME*LYS - 26.5946*LYS $; \mathrm{R}^{2}=0.23$ ), which showed a better relationship with increasing levels of ME and DL (Figure 5).

Figure 5. The duodenal villus: crypt ratio based on metabolizable energy and digestible lysine.

RVDC $=5.6713-0.4519 * \mathrm{ME}+1171.798 * \mathrm{LYS}+0.0002 *$ $\mathrm{ME}^{2}-0.3789 * \mathrm{ME} * \mathrm{LYS}-26.5946 * \mathrm{LYS}^{2},\left(\mathrm{R}^{2}=0.23\right)$

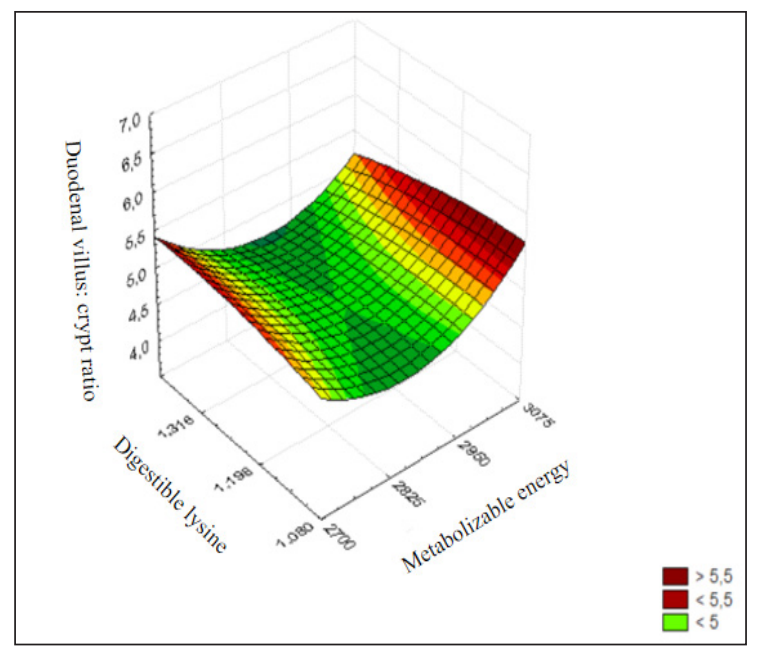

In the jejunum, the villus: crypt ratio showed a linear increase $(\mathrm{P}<0.05)$ with increasing levels of $\mathrm{DL}\left(\mathrm{RVCJ}=0.90467+2.3069^{*} \mathrm{LYS}, \mathrm{R}^{2}=0.88\right)$. There were no differences $(\mathrm{P}>0.05)$ for the villus: crypt ratio in the ileum.

After poultry hatch, the morphologic and functional development of organs occurs, with a consequent increase in the area of absorption and secretion of enzymes, suggesting that the morphometric increase in digestive organs and their enzymatic activity are coordinated by the efficient supply of nutrients.

According Maiorka et al. (2003), the number of villi per area was higher in the duodenum 48 hours, and in the duodenum and jejunum 72 hours post hatch, in poultry that suffering food and water restriction in poultry, compared to poultry that received feed and water ad libitum. The authors concluded that this increase was related to the reduction in gut size of these poultry.

The intestinal mucosa is responsible for the absorption of food, which is held in the villi through the enterocytes. The number of villi is associated with the enterocytes of the villi, and their size increase reflects a greater absorption of food (MACARI; MAIORKA, 2000). Freitas et al. (2008) reported that most villus height is related to performance results, and that poultry with larger villi have higher weight gains and better feed conversion. Thus, the larger the size of the villi, the greater the ability of digestion and absorption of nutrients, due to the larger contact area and the level of enzyme effectiveness between the mucosa and intestinal lumen.

Pelicano et al. (2003) studied the intestinal morphometry of poultry on diets with different probiotics, and found that the highest value of crypt depth was related to an increased cell proliferative activity, the purpose of which is to ensure an adequate rate of epithelial renewal, offsetting losses in the heights of the villi. These results partially corroborate with an experiment conducted by Duarte et al. (2012) who evaluated different energy levels (3200 and $3600 \mathrm{kcal} / \mathrm{kg}$ ) and feeding programs, and noted that the highest level of energy led to a higher villus height and improved performance of the poultry.

\section{Conclusions}

Diets with $3075 \mathrm{kcal} / \mathrm{kg}$ and $1.403 \mathrm{DL} \%$ provided better intestinal morphometric characteristics of broiler chickens 1 to 10 days of age.

\section{References}

CELLA, P. S.; MURAKAMI, A. E.; FRANCO, J. R. F. Níveis de lisina digestível em dietas baseadas no conceito de proteína ideal para frangos de corte na fase inicial. 
Ciência Animal Brasileira, Goiânia, v. 10, n. 1, p. 101106, 2009.

DUARTE, K. F.; JUNQUEIRA, O. M.; BORGES, L. L.; SANTOS, E. T.; MARQUES, R. H.; QUADROS, T. C. O.; DOMINGUES, C. H. F. Desempenho e morfometria duodenal de frangos de corte submetidos a diferentes níveis de energia e programas de alimentação de 42 a 57 dias de idade. Ciência Animal Brasileira, Goiânia, v. 13, n. 2, p. 197-204, 2012.

FRAGA, A. L.; MOREIRA, I.; FURLAN, A. C.; BASTOS, A. O.; OLIVEIRA, R. P.; MURAKAMI, A. E. Lysine requeriments of start barrow from two genetic groups fed on low crude protein diets. Brazilian Archives of Biology and Tecnology, Curitiba, v. 51, n. 1, p. 49-56, 2008.

FREITAS, E. R.; SAKOMURA, N. K.; DAHLKE, F.; SANTOS, F. R.; BARBOSA, N. A. A. Desempenho, eficiência de utilização dos nutrientes e estrutura do trato digestório de pintos de corte alimentados na fase préinicial com rações de diferentes formas físicas. Revista Brasileira de Zootecnia, Viçosa, MG, v. 37, n. 1, p. 7378, 2008.

GONZALES, E.; SARTORI, J. R. Crescimento e metabolismo muscular. In: MACARI, M.; FURLAN, R. L; GONZALES, E. (Ed.). Fisiologia aviária aplicada a frangos de corte. Jaboticabal: FUNEP/UNESP, 2002. p. 279-297.

LEANDRO, N. S. M.; CAFÉ, M. B.; STRINGHINI, J. H.; MORAES FILHO, R.; MOURA, K. A. de; SILVA JÚNIOR, R. P. da. Plano nutricional com diferentes níveis de proteína bruta e energia metabolizável na ração, para frangos de corte. Revista Brasileira de Zootecnia, Viçosa, v. 32, n. 6, p. 620-631, 2003.

MACARI, M.; MAIORKA, A. Função gastrinestinal e seu impacto no rendimento avícola. In: CONFERÊNCIA APINCODE CIÊNCIA E TECNOLOGIA AVÍCOLAS, 2000, São Paulo. Anais... Campinas: Fundação Apinco de Ciência e Tecnologia Avícolas, 2000. p. 161-174.

MAIORKA, A.; SANTIN, E.; DAHLKE, F.; BOLELI, I. C.; FURLAN, R. L.; MACARI, M. Posthatching water and feed deprivation affect the gastrointestinal tract and instestinal mucosa development of boiler chicks. Journal of Applied Poultry Research, Oxford, v. 12, n.4, p. 483492, 2003.
NUNES, R. V.; ROSTAGNO, H. S.; GOMES, P. C.; VILELA, C. G.; POZZA, P. C.; ARAUJO, M. S. Coeficientes de metabolizabilidade da energia bruta de diferentes ingredientes para frangos de corte. Revista Brasileira de Zootecnia, Viçosa, MG, v. 37, n. 1, p. 8994, 2008.

NUNES, R. V.; SAVOLDI, T. L.; TSUTSUMI, C. Y.; MEZA, S. K. L.; BROCH, J.; SOUZA, C. de; HENZ, J. R. Levels of metabolizable energy and digestible lysine for broiler chicks 8-21 days of age. Semina: Ciências Agrárias, Londrina, v. 36, n. 6, p. 3935-3946, 2015.

PELICANO, E. R. L.; SOUZA, P. A.; SOUZA, H. B. A.; OBA, A.; NORKUS, E. A.; KODAWARA, L. M.; LIMA, L. M. A. Morfometria e ultra-estrutura da mucosa intestinal de frangos de corte alimentados com dietas contendo diferentes probióticos. Revista Portuguesa de Ciências Veterinárias, Lisboa, v. 98, n. 547, p. 125-134, 2003.

ROSTAGNO, H. S.; ALBINO, L. F. T.; DONZELE, J. L.; GOMES, P. C.; OLIVEIRA, R. F.; LOPES, D. C.; FERREIRA, A. S.; BARRETO, S. L. T.; EUCLIDES, R. F. Tabelas brasileiras para aves e suínos: composição de alimentos e exigências nutricionais. Viçosa, MG: Universidade Federal de Viçosa, 2011. 186 p.

SAKOMURA, N. K.; LONGO, F. A.; RABELLO, C. B.; WATANABE, K.; PELÍ́CIA, K.; FREITAS, E. R. Efeito do nível de energia metabolizável da dieta no desempenho e metabolismo energético de frangos de corte. Revista Brasileira de Zootecnia, Viçosa, MG, v. 33, n. 6, p. 1758-1767, 2004.

SILVA, D. J.; QUEIROZ, A. C. D. Análise de alimentos: métodos químicos e biológicos. 3. ed. Viçosa, MG: UFV, 2004. $235 \mathrm{p}$.

SILVA, J. H. V.; SILVA, M. B.; SILVA, E. L.; JORDÃO FILHO, J.; RIBEIRO, M. L. G.; COSTA, F. G. P.; DUTRA JÚNIOR, W. M. Energia metabolizável de ingredientes determinada com codornas japonesas (Coturnixcoturnixjaponica). Revista Brasileira de Zootecnia, Viçosa, MG, v. 32, n. 6, p. 1912-1918, 2003.

SILVA, J. H. V.; ALBINO, L. F. T.; NASCIMENTO, A. H. Níveis de energia e relações energia:proteína para frangos de corte de 22 a 42 dias de idade. Revista Brasileira de Zootecnia, Viçosa, v. 30, n. 6, p. 17911800, 2001. 
